\title{
NEW FOSSIL RECORDS OF PLEISTOCENE MARINE MOLLUSKS IN SOUTHERN BRAZIL
}

\author{
RENATO PEREIRA LOPES \\ Setor de Paleontologia, Instituto de Oceanografia, FURG, Campus Carreiros, 96201-900, Rio Grande, RS, Brasil. \\ paleonto_furg@yahoo.com.br \\ LUIZ RICARDO L. SIMONE \\ Museu de Zoologia, Universidade de São Paulo, Cx.P. 42494, 04218-970, São Paulo, SP, Brasil.lrsimone@usp.br
}

\begin{abstract}
Fossils of the gastropods Diodora patagonica, Zidona dufresnei, Olivancillaria carcellesi, Lamniconus lemniscatus carcellesi and the bivalve Arcinella brasiliana are registered for the first time from the outcrops of Chuí Creek, on the coastal plain of Rio Grande do Sul State, southernmost Brazil, together with other taxa previously known elsewhere. The specimens were collected in a shallow Pleistocene marine facies exposed at the base of the banks of the creek, in a fossil concentration possibly formed by storm events. The taxa described here live in shallow environments (with the exception of A. brasiliana and Z. dufresnei) with sandy bottoms (except for D. patagonica, T. patagonica, B. odites, C. rhizophorae and $A$. brasiliana). The presence of $L$. lemniscatus carcellesi, found living today only in Uruguay and Argentina, indicates a wider distribution for this taxon during the late Pleistocene.
\end{abstract}

Key words: Bivalvia, biogeography, Gastropoda, Mollusca, Pleistocene, Rio Grande do Sul State.

\begin{abstract}
RESUMO - Fósseis dos gastrópodes Diodora patagonica, Zidona dufresnei, Olivancillaria carcellesi, Lamniconus lemniscatus carcellesi e do bivalve Arcinella brasiliana são registrados pela primeira vez para os afloramentos do Arroio Chuí, na planície costeira do estado do Rio Grande do Sul, no extremo sul do Brasil, juntamente com outros táxons previamente encontrados em diversas localidades. Os espécimes foram coletados em uma fácies marinha rasa de idade pleistocênica exposta na base das barrancas do Arroio Chuí, em concentração fossilífera possivelmente formada por eventos de tempestade. Os táxons aqui descritos vivem em pequenas profundidades (exceto $A$. brasiliana e $Z$. dufresnei) em fundos arenosos (à exceção de $D$. patagonica, T. patagonica, B. odites, C. rhizophorae e A. brasiliana). A presença de L. lemniscatus carcellesi, que atualmente ocorre apenas no Uruguai e Argentina, indica uma distribuição mais ampla deste táxon durante o Pleistoceno tardio.
\end{abstract}

Palavras-chave: Bilvalvia, biogeografia, Gastropoda, Mollusca, Pleistoceno, Rio Grande do Sul.

\section{INTRODUCTION}

The coastal plain of Rio Grande do Sul State (CPRS) is a Quaternary geomorphological unit known by the presence of several outcrops containing fossils of marine organisms. Such remains are most conspicuous in large concentrations in the southern portion of the continental shelf (Figueiredo, 1975). These concentrations are affected by storm waves during autumn and winter, which remove the fossil remains and transport them to the coast, forming on the beach large konzentrat-lagerstätte known as "concheiros" (Lopes \& Buchmann, 2008). The fossil remains found in these concentrations are predominantly bivalves, but gastropods are also common.

Apart from the continental shelf, fossils of marine mollusks were also recorded in several continental outcrops, far from the present coastline, such as the towns of Pelotas and Pedro Osório (Bianchi, 1969), Santa Vitória do Palmar (Closs \& Forti, 1971; Lima \& Buchmann, 2005) and São Lourenço do
Sul and Capão do Leão (Godolphim et al., 1989). Forti (1969) has also described fossil shells from drill holes in the towns of Rio Grande and Palmares do Sul. The presence of these fossils in continental areas is correlated to Pleistocene and Holocene marine transgressions that formed the CPRS (Villwock \& Tomazelli, 1995). In Santa Vitória do Palmar, such fossils have been found in Chuí Creek (Closs \& Forti, 1971) and Mangueira Lake (Lima \& Buchmann, 2005). However, those described from Chuí Creek were found in dredged sediments and scattered along the bed of the creek, without precise stratigraphic control. Closs \& Forti (1971) described several fossils from two localities in Chuí Creek: one near the town of Chuí (samples E1 and E2) and the other on the bridge on the road between Santa Vitória do Palmar and Hermenegildo beach. The first locality is near the coastline, and the outcrop where the shells were collected corresponds to an estuarine environment developed during the Holocene sea-level transgression around $6 \mathrm{ky} \mathrm{BP}$ (Caron, 2007). The fossils collected from the second locality are certainly Pleistocene in age, based on their stratigraphic 
position and ages obtained from mammalian remains found in the fossiliferous level above the marine facies (Lopes et al., 2010; Lopes et al., 2011), but those authors did not describe the stratigraphic position, so it is probable that the remains were found scattered along the bed of the creek, as it can be seen today.

The remains described here are taxa that have not been recorded from this locality by Closs \& Forti (1971) and represent the first Pleistocene fossil marine remains found in a precise stratigraphic position, associated with an assemblage of taxa that inhabit shallow marine environments with sandy bottoms (Lopes, 2010). Besides the importance of the stratigraphic position of the remains, the occurrences presented here increase the diversity of fossil molluscan remains from Chuí Creek and the CPRS.

\section{GEOLOGICAL SETTING}

Chuí Creek is located in the southernmost portion of the CPRS, in Santa Vitória do Palmar town. The creek flows over a plain located between two sandy barriers formed by marine transgressions, namely Barrier II, situated westwards, and Barrier III eastwards (Tomazelli et al., 2000).

The sedimentary sequence exposed along the banks of the creek exhibits a shallow marine facies at the base, composed of fine sand with parallel and low-angle cross stratification, containing ichnofossils Ophiomorpha nodosa. This layer is more than $4 \mathrm{~m}$ in thickness, but only some $2 \mathrm{~m}$ are exposed along the banks above the creek bed. The fossil shell concentration occurs near the base of the exposed portion of the layer (Figure 1)

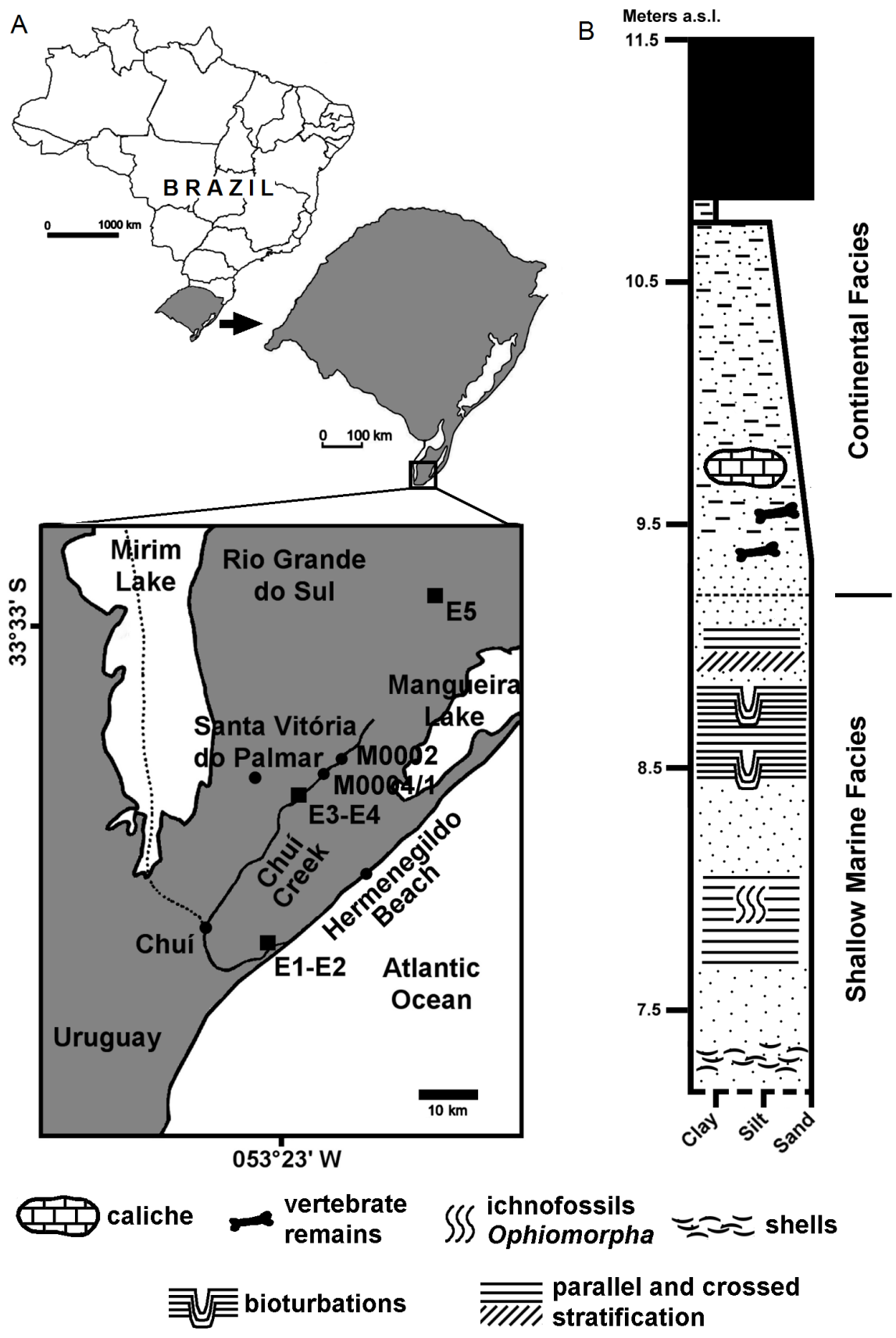

Figure 1. A, location map of Chuí Creek, southernmost portion of the CPRS; B, stratigraphic column of the study area. 
and measures some $10 \mathrm{~cm}$ in thickness, and is located some $7.5 \mathrm{~m}$ above the present sea level. The stratigraphic position suggests that this concentration was built during the marine transgression that formed Barrier II. The marine facies is overlain by a $\sim 2 \mathrm{~m}$ thick layer containing fossils of Pleistocene mammals preserved in a fluvial meandering environment (Lopes et al., 2009); the uppermost portion of the sequence is formed by Holocene sediments.

\section{MATERIAL AND METHODS}

The fossil molluscan assemblage was identified during field work in Chuí Creek in October 2010, when an extreme drought exposed the base exposed the base of the banks and revealed three shell accumulations positioned at the same stratigraphic level. Two (M0001 and M0004) are located about $600 \mathrm{~m}$ to the north of the bridge on the road between Santa Vitória do Palmar and Hermenegildo beach, while the other (M0002) is located some $2 \mathrm{~km}$ to the north. Bulk samples of the shells were collected, and sand was removed with a $2 \mathrm{~mm}$ mesh sieve. Specimens that could be identified (615 bivalves and 17 gastropods) were hand picked among unidentifiable fragments.

The specimens described here were first mentioned by Lopes (2010), and now an updated taxonomic identification is presented. All specimens are housed in the paleontological collection of the Laboratório de Geologia e Paleontologia of Universidade Federal do Rio Grande (FURG). Identification of specimens was based mostly on Rios (1994), revision of previous records of marine fossils for the CPRS (Forti, 1969; Closs \& Forti, 1971; Godolphim et al., 1989) and comparison with Recent specimens. All measurements are presented in millimeters (length by height).

Abbreviations. LGP-W, Laboratório de Geologia e Paleontologia - Mollusca, Universidade Federal do Rio Grande; CPRS, coastal plain of Rio Grande do Sul State.

\section{SYSTEMATIC PALEONTOLOGY}

\author{
Class GASTROPODA Cuvier, 1797 \\ Order VETIGASTROPODA Salvini-Plawen, 1989 \\ Family FISSURELLIDAE Fleming, 1822 \\ Genus Diodora Gray, 1921
}

Diodora patagonica (d'Orbigny, 1847)

(Figure 2A)

Material. Specimen LGP-W0235.

Comments. Characteristic shell exhibiting similar-sized radial ribs. Surface of examined specimen exhibits signs of corrosion, mostly on the internal surface. This limpet species usually lives in the infratidal zone on hidden surfaces of rocks; microphage and herbivore habits.

Measurements. Length: 27.0; maximum width: 18.5; orifice length: 3.0 ; orifice width: 1.0 .

\author{
Family TROCHIDAE Rafinesque, 1815 \\ Genus Tegula Lesson, 1835 \\ Tegula patagonica (d'Orbigny, 1840)
}

(Figure 2B)

Material. Specimen LGP-W0269.

Comments. Shell externally sculpted with small longitudinal ridges; subcircular aperture, protoconch broken. Original color pattern faint but still visible, with spiral brown streaks; internal pearly lining of the outer lip preserved.

Measurements. 10 by 14; spire: 1.5 ; aperture: 4.5 .

Order CAENOGASTROPODA Cox, 1960

Family CALYPTRAEIDAE Lamarck, 1809

Genus Bostrycapulus Olsson \& Harbison, 1953

Bostrycapulus odites Collin, 2005

(Figure 2C)

Material. Specimen LGP-W0263.

Comments. Listed as Crepidula cf. aculeata in Lopes (2010). Shell ovate, with apex spirally curved, surface ornamented with longitudinal ribs. Examined specimen white and slightly corroded, without periostracum. Species that inhabits hard substrates in the infratidal zone.

Measurements. Length: 17; height: 13.

Family VOLUTIDAE Rafinesque, 1815

Genus Zidona Adams \& Adams, 1853

Zidona dufresnei (Donovan, 1823)

(Figure 2D)

Material. Specimen LGP-W0171.

Comments. Listed by Lopes (2010) as Adelomelon beckii (Broderip, 1836). An incomplete shell, outer lip fragmented; white-colored and corroded, without periostracum or the characteristic apical spur (Smith, 1942). Longitudinal growth lines are visible. The external face of the last whorl exhibits ichno-traces of the genera Entobia and Caulostrepsis, produced by clionid sponges and serpulid polychaetes, respectively.

Measurements. Length: 163.0; maximum width: 39.0; spire height: 26.0; aperture length: 128.0; aperture width: 20.5.

Genus Adelomelon Dall, 1906

\section{Adelomelon brasiliana (Lightfoot, 1786)}

(Figure 2E)

Material. Specimen LGP-W0258.

Comments. An almost complete shell, broken along the outer lip, white-colored and without periostracum. The surface exhibits signs of corrosion and several borings made by unknown organisms.

Measurements. Length: 113.0; height: 76.0; spire height: 12.0; aperture length: 99.0; aperture width: 40.5 . 
Family OLIVIDAE Latreille, 1825

Genus Olivancillaria d'Orbigny, 1840

Olivancillaria carcellesi Klappenbach, 1965

(Figure 2F)

Material. Specimen LGP-W0172.

Comments. A well-preserved shell, complete and without signs of abrasion or bioerosion. Light gray-colored surface, without periostracum. Smooth longitudinal growth lines visible on the middle-posterior portion of the last whorl. Signs of corrosion are visible on the ventral side and on the palatal and columellar margins.

Measurements. Length: 53.0; maximum width: 32.0; spire height: 5.0; aperture length: 48.0; aperture width: 14.5.

\section{Olivancillaria urceus (Röding, 1798)}

(Figure 2G)

Material. Specimen LGP-W0173.

Comments. A shell fragmented on the outer lip and part of the dorsal surface. White-colored, abraded and without periostracum; longitudinal growth lines faint but visible. Ichnotraces Entobia and Caulostrepsis present. Minute puncturings on the posterior margin of the last whorl suggest previous external colonization by bryozoans.

Measurements. Length: 36.5; maximum width: 27.5; spire height: 4.0; aperture length: 30.0; aperture width: 8.5 .

\section{Olivancillaria deshayesiana (Duclos, 1857)}

(Figure 2H)

Material. Specimen LGP-W0174.

Comments. A fragmentary specimen, without inner lip. Spire well preserved, more inflated than in Olivancillaria urceus (Roding, 1798). White-colored, with smooth surface due to abrasion; without periostracum.

Measurements. Length: 37.0; maximum width: 21.0; spire height: 6.5 .

Family CONIDAE Rafinesque, 1815

Genus Lamniconus da Motta, 1991

\section{Lamniconus lemniscatus carcellesi (Martins, 1945)}

(Figure 2I)

Material. Specimen LGP-W0175.

Comments. Listed as Conus sp. by Lopes (2010). Low and straight spire, formed by 7 or 8 whorls, barely visible because of abrasion. External surface without ridges or protuberances, with faint longitudinal growth lines visible on the outer surface. Outer lip and dorsal side partially fragmented. Light gray color, without periostracum.

This taxon has a complex systematic history, dating back to the identification of Conus carcellesi by Martins (1945), based on specimens from the Argentinean coast. Vink (1986) considered $C$. platensis and $C$. iheringi, described originally by Frenguelli (1946), as synonyms of $C$. carcellesi, and grouped all three taxa as a subspecies of Lamniconus lemniscatus, namely L. lemniscatus carcellesi. Rios (1994) considered that $C$. carcellesi and C. iheringi were junior synonyms of C. clerii Reeve, 1843; however, the specimen illustrated by Reeve is morphologically distinct from $C$. carcellesi, with a concave spire. According to J.K. Tucker (pers. comm. 2010), L. clerii (formerly C. clerii) and L. lemniscatus are indeed distinct species, and L. lemniscatus carcellesi lives in Uruguay and Argentina, while L. lemniscatus lemniscatus inhabits the Brazilian coast (a comprehensive revision can be found in Tucker, 2010). Despite the morphological variations observed in L. lemniscatus, the morphology of the specimen described here clearly indicates that it is indeed a L. lemniscatus carcellesi. This record implies that this taxon had a wider latitudinal distribution during the late Pleistocene than today. Measurements. Length: 43.5; maximum width: 21.0; spire height: 7.0; aperture length: 34.0; aperture width 2.5.

\author{
Class BIVALVIA Linné, 1758 \\ Order OSTREOIDA Waller, 1978 \\ Family OSTREIDAE Lamarck, 1809 \\ Genus Crassostrea Sacco, 1897
}

Crassostrea rhizophorae (Guilding, 1828)

(Figure 3A)

Material. Specimen LGP-W0236.

Comments. An incomplete valve, fragmented along the anterior margin, with minor fragmentation near the umbo and central-right side. Light gray color, without signs of corrosion, abrasion or bioerosion.

Measurements. Length: 54.0; height: 84.5.

\author{
Order MYOIDA Stoliczka, 1870 \\ Family CORBULIDAE Lamarck, 1818 \\ Genus Corbula Bruguière, 1797 \\ Corbula caribaea d'Orbigny, 1853
}

(Figure 3B)

Material. Specimens LGP-W0268a to LGP-W0268r.

Comments. Valves oval elongated; the anterior end is rounded and posterior one pointed. Surface ornamented with concentric ribs. Examined shells well preserved, complete, including one double-valved individual. All white-colored, without periostracum and slightly corroded.

Measurements. Range-average, $\mathrm{N}=18$ : length: 3.5-7.5 (mean = 5.1); height: 5.0-10.5 $($ mean $=7.3)$.

$$
\begin{gathered}
\text { Family NOETIIDAE Stewart, } 1930 \\
\text { Genus Noetia Gray, } 1857
\end{gathered}
$$

Noetia bisulcata (Lamarck, 1819)

(Figure 3C)

Material. Specimen LGP-W0267.

Comments. Subrectangular shell, ornamented with radial ribs. Complete valve, white and slightly corroded, without abrasion or bioerosion.

Measurements. Length: 34; height: 22. 


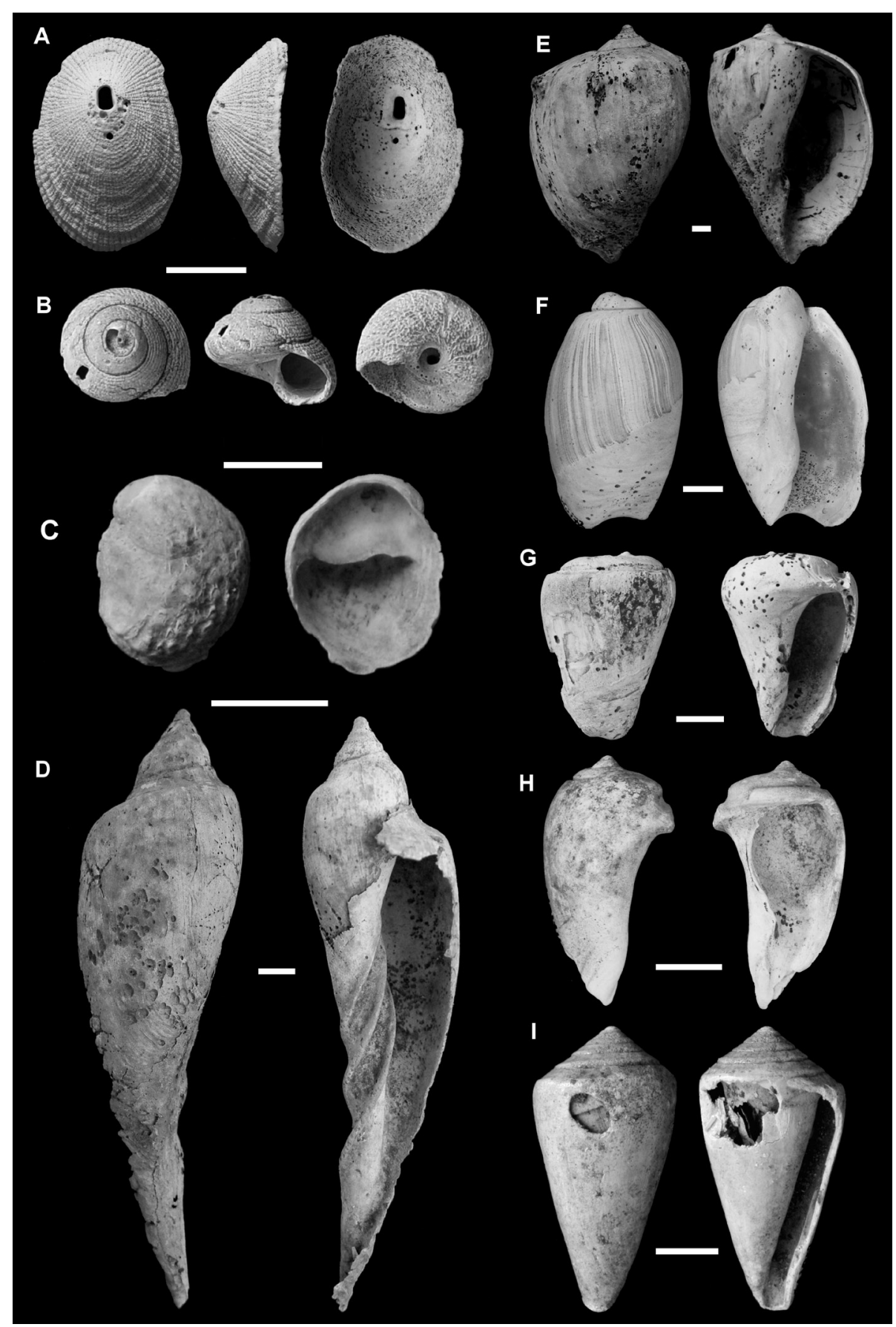

Figure 2. Gastropods from the CPRS assemblage. A, Diodora patagonica, LGP-W0235; B, Tegula patagonica, LGP-W0269; C, Bostrycapulus odites, LGP-W0263; D, Zidona dufresnei, LGP-W0171; E, Adelomelon brasiliana, LGP-W0258; F, Olivancillaria carcellesi, LGP-W0172; G, Olivancillaria urceus, LGP-W0173; H, Olivancillaria deshayesiana, LGP-W0174; I, Lamniconus lemniscatus carcellesi, LGP-W0175. Scale bars = 10 mm.

Order VENEROIDA Adams \& Adams, 1884

Family CHAMIDAE Lamarck, 1809

Genus Arcinella Schumacher, 1817

Arcinella brasiliana (Nicol, 1953)

(Figure 3D)

Material. Specimen LGP-W0176.

Comments. Subquadrate examined shell, partially fragmented in its central portion. Specimen well preserved, white-colored and without periostracum. Seven radial ribs, without spines; ornamentation in the form of thin radial ridges intercrossed with concentric ones near the margin of the valve.

Measurements. Length: 41.5; height: 43.0.

Family CARDIIDAE Lamarck, 1809

Genus Trachycardium Moerch, 1853

Trachycardium muricatum Linné, 1758

(Figure 3E)

Material. Specimens LGP-W0237, LGP-W0238 and LGP-W0239. 
Comments. White shells, without periostracum or signs of abrasion, with radial ribs well preserved. Specimen LGP-W0237 is represented by a complete valve; specimens LGP-W0238 and LGP-W0239 are fragmentary and corroded on their internal surfaces. Specimen LGP-W0239 is fragmented near the umbo and represents a juvenile individual.

Measurements. LGP-W0237: length: 36.5; height: 38.5.

Family VENERIDAE Rafinesque, 1815

Genus Chione von Mühlfeld, 1811

Chione cancellata (Linné, 1767)

(Figure 3F)

Material. Specimens LGP-W0241 to LGP-W0250.

Comments. Shells white, without periostracum or original color pattern. The specimen LGP-W0241 does not exhibit abrasion or corrosion, and its external ornamentation is well preserved. The central portion of the shell is pierced by traces mainly related to the ichnogenus Gastrochaenolites Leymarie, 1842. Specimen LGP-W0242 also bears similar traces, but is very corroded and abraded. Specimens LGP-W0243, LGP-W0244 and LGP-W0248 are internally and externally corroded.

Measurements. LGP-W0241: length: 16.5; height: 19.5.

\section{DISCUSSION AND CONCLUSIONS}

Several fossil marine mollusks have been described from specimens collected in Chuí Creek and other places in Santa Vitória do Palmar (Closs \& Forti, 1971). The gastropods Tegula patagonica, Bostrycapulus odites, Adelomelon brasiliana, Olivancillaria urceus and Olivancillaria deshayesiana, and the bivalves Chione cancellata, Trachycardium muricatum, Crassostrea rhizophorae, Corbula caribaea and Noetia bisulcata have been previously recorded in other outcrops, but this is the first description of these taxa from Chuí Creek. The gastropods Diodora patagonica, Zidona dufresnei, Olivancillaria carcellesi, Lamniconus lemniscatus carcellesi, and the bivalve Arcinella brasiliana are described for the first time for the CPRS, thus increasing the known diversity of fossil mollusks from southernmost Brazil (Table 1).

Except for Diodora patagonica, Tegula patagonica, Bostrycapulus odites, Crassostrea rhizophorae and Arcinella brasiliana, which live attached to rocks or mussels, and Zidona dufresnei and Adelomelon brasiliana, which live at greater depths, all taxa described here are shallow, soft bottom dwellers. It seems likely that this fossil assemblage was concentrated in a beach environment, apparently by storm events (Lopes, 2010). The specimens of $Z$. dufresnei, A. brasiliana, O. urceus and $O$. deshayesiana discussed here show features that indicate postmortem reworking; the presence of bioerosion indicates exposures at the sediment-water interface for a long time.

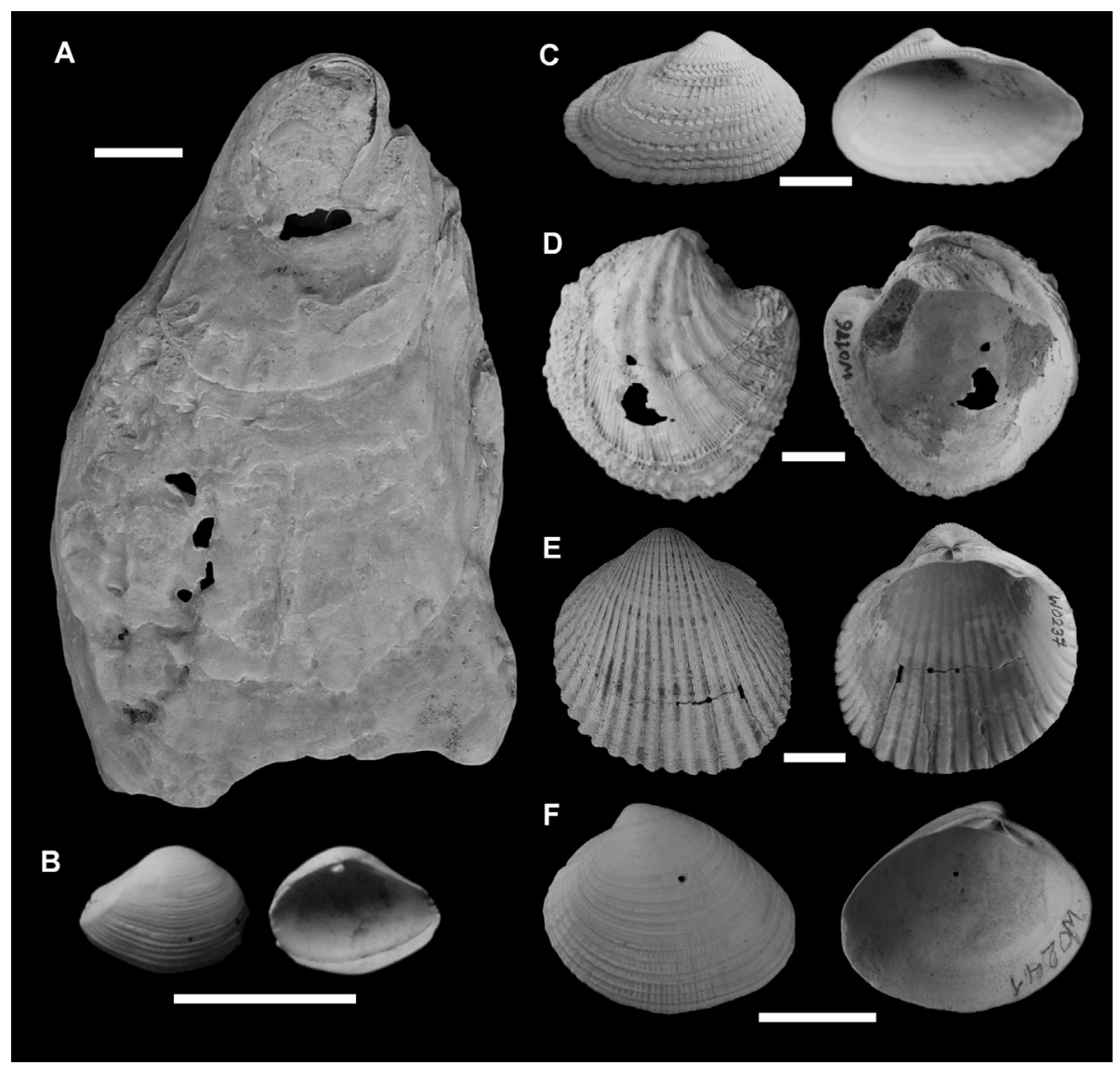

Figure 3. Bivalves from the CPRS assemblage. A, Crassostrea rhizophorae, LGP-W0236; B, Corbula caribaea, LGP-W0268a; C, Noetia bisulcata, LGP-W0267; D, Arcinella brasiliana, LGP-W0176; E, Trachycardium muricatum, LGP-W0237; F, Chione cancellata, LGP-W0242. Scale bars $=10 \mathrm{~mm}$. 
Table 1. Updated list of fossil mollusks from continental outcrops of the CPRS, ordered by date of first publication. Although the taxa from Martínez et al. (2006) were collected on the Uruguayan margin of Chuí Creek, in a geological sense the fossiliferous outcrop belongs to the CPRS.

\author{
Bianchi (1969) - Pelotas /Pedro Osório \\ Ostrea equestris Say, 1834 \\ Ostrea puelchana d'Orbigny, 1841 \\ Crassostrea virginica (Gmelin, 1791)
}

Forti (1969) - Rio Grande/Palmares do Sul

Eunucula semiornata (d'Orbigny, 1846)

Nucula puelcha d'Orbigny, 1846

Lunarca ovalis (Bruguière, 1789)

Anadara brasiliana (Lamarck, 1819)

Noetia bisulcata (Lamarck, 1819)

Glycymeris longior (Sowerby, 1833)

Plicatula gibbosa (Lamarck, 1801)

Chlamys tehuelchus (d'Orbigny, 1846)

Crassinella maldonadensis Pilsbry, 1897

Carditamera plata (Ihering, 1907)

Trachycardium muricatum (Linné, 1758)

Pitar rostratus (Koch, 1844)

Protothaca antiqua (King \& Broderip, 1835)

Anomalocardia brasiliana (Gmelin, 1791)

Amiantis purpuratus (Lamarck, 1818)

Clausinella gayi (Hupé, 1854)

Mactra patagonica d'Orbigny, 1846

Mactra marplatensis Doello-Jurado, 1918

Donax hanleyanus Philippi, 1842

Abra aequalis (Say, 1822)

Semele bellastriata (Conrad, 1837)

Corbula caribaea d'Orbigny, 1842

Corbula iheringiana Pilsbry, 1897

Corbula nasuta Sowerby, 1833

Erodona mactroides (Bosc, 1802)

Tegula patagonica (d'Orbigny, 1840)

Halistylus columna Dall, 1890

Caecum imbricatum Carpenter, 1857

Finella dubia (d'Orbigny, 1842a)

Epitonium georgettina Kiener, 1839

Odostomia seminuda (Adams, 1837)

Turbonilla interrupta (Totten, 1835)

Fossarus florius (Philippi, 1841 )

Bostrycapulus odytes Collin, 2005

Crepidula protea d'Orbigny, 1835

Natica isabelleana d'Orbigny, 1840

Anachis obesa (Adams, 1845)

Anachis isabellei (d'Orbigny, 1841)

Anachis sertulariarum (Orbigny, 1841)

Nassarius scissuratus Dall, 1889

Nassarius ambiguus Pulteney, 1799

Olivancillaria deshayesiana (Duclos, 1857)

Olivella puelcha (Duclos, 1840)

Olivella tehuelcha (Duclos, 1840)

Drillia patagonica (d'Orbigny, 1841)

Hastula cinerea (Born, 1778)

Rictaxis punctostriatus (Dall, 1871 )
Acteocina bidentata (d'Orbigny, 1841)

Acteocina candei (d'Orbigny, 1842)

Closs \& Forti (1971) - Santa Vitória do Palmar

Brachidontes sp.

?Venericardia $\mathrm{cf}$ tridentata (Say, 1826)

Phlyctiderma semiaspera (Philippi, 1836)

Cardium delicatum Smith, 1915

Chione paphia (Linné, 1767)

Mactra isabelleana d'Orbigny, 1846

Tagelus plebeius (Lightfoot, 1786)

Corbula patagonica d'Orbigny, 1846

Cadulus sp.

Tegula patagonica (d'Orbigny, 1840)

Littoridina (= Heleobia) australis (d'Orbigny, 1835)

Parodizia uruguayensis Medina, 1959

Odostomia seminuda (Adams, 1837)

Turbonilla cf. uruguayensis Pilsbry, 1897

Buccinanops gradatum (Deshayes, 1844)

Buccinanops globulosum (Kiener, 1834)

Adelomelon brasiliana (Lightfoot, 1786)

Godolphim et al. (1989) - several localities

Crassostrea rhizophorae (Guilding, 1828)

Laevicardium brasilianum (Lamarck, 1819)

Diplodonta punctata (Say, 1822)

Adrana patagonica (d'Orbigny, 1846)

Pholas campechiensis Gmelin, 1791

Dosinia concentrica (Born, 1778)

Chione cancellata (Linné, 1767)

Divaricella quadrisulcata (d'Orbigny, 1842)

Anadara chemnitzi (Philippi, 1851)

Transenella sp.

Felaniella vilardebona (d'Orbigny, 1846)

Tellina radiata Linné, 1758

Olivancillaria urceus (Röding, 1798)

Bulla striata Brugière, 1792

Crepidula intratesta Simone, 2006

Calyptraea centralis Conrad, 1841

Cylichna discus Watson, 1883

Martínez et al. ( 2006) - Chuí Creek

Petricola stellae Narchi, 1975

Heleobia charruana (d'Orbigny, 1835)

Parvanachis paessleri (Strebel, 1905)

This paper

Arcinella brasiliana (Nicol, 1953)

Zidona dufresnei (Donovan, 1823)

Olivancillaria carcellesi Klappenbach, 1965

Lamniconus lemniscatus carcellesi (Martins, 1945)

Diodora patagonica (d'Orbigny, 1847) 
All taxa studied here can be found living today on the coast of Rio Grande do Sul State (Rios, 1994; Capitoli, 1998; Gianuca, 1998), except for Lamniconus lemniscatus carcellesi, which is found living just on the continental shelf off Uruguay and Argentina. Chione cancellata and Arcinella brasiliana are either very scarce or do not occur in the coast of Rio Grande do Sul today, because are not recorded from studies on living communities (Absalão, 1991; Capitoli, 1998; Gianuca, 1998). This pattern may have been caused by distinct paleoceanographic conditions in the past or by some sort of biogeographic barrier, possibly related to the marine transgressions that affected the area during the late Pleistocene.

\section{ACKNOWLEDGEMENTS}

The authors expresses their gratitude to C.E. Bemvenuti and L.A. Colling of Laboratório de Ecologia de Comunidades Bentônicas, Instituto de Oceanografia (FURG) for helping with identification of specimens; to J.K. Tucker (Illinois Natural History Survey) for useful comments and discussions regarding the systematics of the conid specimen described herein; and to S. Martínez (Facultad de Ciencias, Montevideo) and M.G. Simões (UNESP, Botucatu) for useful comments on the manuscript. This research was made possible with the financial support (doctorship grant) from the Conselho Nacional de Desenvolvimento Científico e Tecnológico - CNPq.

\section{REFERENCES}

Absalão, R.S. 1991. Environmental discrimination among soft-bottom mollusc associations off Lagoa dos Patos, south Brazil. Estuarine, Coastal and Shelf Science, 32:71-85.

Bianchi, L.A. 1969. Bancos de ostreídeos pleistocênicos da Planície Costeira do Rio Grande do Sul. Iheringia, Série Geologia, 2:3-40.

Capitoli, R. 1998. Bentos da plataforma continental. In: U. Seeliger; C. Odebrecht \& J.P. Castello (eds.) Os ecossistemas costeiro e marinho do extremo sul do Brasil, Editora Ecoscientia, p. 131-134.

Caron, F. 2007. Depósitos sedimentares associados à desembocadura do Arroio Chuí (planície costeira do Rio Grande do Sul) e suas relações com as variações do nível do mar durante o Holoceno. Programa de Pós-Graduação em Geociências, Universidade Federal do Rio Grande do Sul, M.Sc. thesis, 81 p.

Closs, D.L. \& Forti, I.R.S. 1971. Quaternary mollusks from the Santa Vitória do Palmar County. Iheringia, Série Geologia, 4:19-58.

Figueiredo Jr., A.G. 1975. Geologia dos depósitos calcários biodetríticos da plataforma continental do Rio Grande do Sul. Programa de Pós-Graduação em Geociências, Universidade Federal do Rio Grande do Sul, M.Sc. thesis, 72 p.

Forti, I.R.S. 1969. Cenozoic mollusks from the drill-holes Cassino and Palmares do Sul of the coastal plain of Rio Grande do Sul. Iheringia, Série Geologia, 2:55-155.

Frenguelli, J. 1946. Espécies del género Conus vivientes en el litoral platense y fósiles en el Neozóico Superior Argentino-Uruguayo. Notas del Museo de La Plata, Paleontologia, 88:231-250.

Gianuca, N.M. 1998. Invertebrados bentônicos da praia. In: U. Seeliger; C. Odebrecht \& J.P. Castello (eds.) Os ecossistemas costeiro e marinho do extremo sul do Brasil, Editora Ecoscientia, p. 127-130.

Godolphim, M.A.; Artusi, L.; Dehnhardt, B.A.; Villwock, J.A. \& Esteves, I.R.F. 1989. Novas evidências da transgressão holocênica na porção média da planície costeira do Rio Grande do Sul. Acta Geologica Leopoldensia, 29:23-36.

Lima, L.G. \& Buchmann, F.S.C. 2005. Novo afloramento fossilífero (Pleistoceno/Holoceno) no sul da planície costeira do Rio Grande do Sul. In: CONGRESSO DA ASSOCIAÇÃO BRASILEIRA DE ESTUDOS DO QUATERNÁRIO, 10, 2005. Resumos Expandidos, Guarapari, ABEQUA, CD-Rom.

Lopes, R.P. 2010. Fósseis pleistocênicos de moluscos marinhos no Arroio Chuí. In: PALEO-RS, 2010. Livro de Resumos, Porto Alegre, UFRGS, p. 45.

Lopes, R.P. \& Buchmann, F.S.C. 2008. Comparação tafonômica entre duas concentrações fossilíferas (shell beds) da planície costeira do Rio Grande do Sul, Brasil. Gaea, 4:65-77, doi:10.4013/gaea.20082.03

Lopes, R.P.; Buchmann, F.S.C.; Caron, F. \& Itusarry, M.E.G. 2009. Barrancas fossilíferas do Arroio Chuí, RS - Importante megafauna pleistocênica no extremo sul do Brasil. In: M. Winge; C. Schobbenhaus; M. Berbert-Born; E.T. Queiroz; D.A. Campos; C.R.G. Souza \& A.C.S. Fernandes (eds.) Sitios Geológicos e Paleontológicos do Brasil, CPRM, v. 2, p. 355-362.

Lopes, R.P.; Dillenburg, S.R. \& Schultz, C.L. 2011. A review of the accumulations of fossil marine mollusks in continental areas of the southernmost Brazilian coast, Rio Grande do Sul State $I n$ : CONGRESSO DAASSOCIAÇÃO BRASILEIRA DE ESTUDOS DO QUATERNÁRIO, 13, 2011. Resumos, Armação dos Búzios, CD-Rom.

Martínez, S.; Rojas, A.; Ubilla, M. Verde, M.; Perea, D. \& Piñero, G. 2006. Molluscan assemblages from the marine Holocene of Uruguay: composition, geochronology and paleoenvironmental signals. Ameghiniana, 43:385-397.

Martins, E.A. 1945. Conus carcellesi, um nuevo gastrópodo marino de La República Argentina. Notas del Museo de La Plata, Zoologia, 88:259-264.

Reeve, L.A. 1843. Conchologia Iconica, or Illustrations of the shells of molluscous animals. London, Reeve Brothers, v. 1, 600 p.

Rios, E.C. 1994. Seashells of Brazil. Rio Grande, Editora da FURG, 368 p.

Smith, M. 1942. A review of the Volutidae. Winter Park, Beal-Maltbie Shell Museum - Rollins College, 127 p.

Tomazelli, L.J.; Dillenburg, S.R. \& Villwock, J.A. 2000. Late Quaternary geological history of Rio Grande do Sul coastal plain, southern Brazil. Revista Brasileira de Geociências, 30:474-476.

Tucker, J.K. 2010. Danker L.N. Vink's 'The Conidae of the Western Atlantic'. The Cone Collector, Special Issue, 14A:1-166.

Villwock, J.A. \& Tomazelli, L.J. 1995. Geologia costeira do Rio Grande do Sul. Notas Técnicas, 8:1-45.

Vink, D.L.N. 1986. The Conidae of the Western Atlantic - Part VI. La Conchiglia, 17:14-18.

Received in March, 2011; accepted in January, 2012. 